\title{
Propositions for a biocultural semiotics
}

\author{
Kathryn Staiano-Ross ${ }^{1}$
}

\begin{abstract}
The author has used the term 'biocultural semiotics' in her previous work, but has never defined this field. She presents twelve propositions that describe and motivate a biocultural semiotics. The author draws on thirty years of field work in Belize and her previous research in cultural and bio-semiotics in support of each of the propositions. Propositions include: biology and culture are so bound as to make a discussion of either without inclusion of the other impossible; both umwelt and the sign are central; every sign is an act of communication; every sign has many interpretant(s); perception is influenced by our physical and cultural umwelt; self is critical to our vision of our place in this umwelt; epigenetic phenomena influence how genes are expressed and effect/affect both phenotype and behaviour; body boundaries are cultural and political creations; the body is a political body and its ownership is always contested; disease and its congeners are cultural constructs; sickness and its signs are created as part of an ongoing personal, social, and political narrative; today we face both uncertainty and opportunity in the natural and cultural sciences. She argues that semiotics possesses the language and methodologies to achieve an understanding of the biological/cultural relationship.
\end{abstract}

Keywords: biocultural semiotics; biosemiotics; ethnosemiotics; semiotics of culture; umwelt

\section{What is biocultural semiotics?}

For two decades I have described much of my work as an exploration into biocultural semiotics. These twenty some years have provided me with an opportunity to think about what was meant at the time that I first employed the term and what biocultural semiotics is to me today. Certainly, under the influence of the biosemioticians, my thoughts about this have evolved. I think it time I explained why I believe biocultural semiotics is a valuable and pragmatic concept. I believe a biocultural semiotics forces the unity of our understanding of all culturebearing organisms in biological terms with our still diminished understanding

$1 \quad$ Author’s address: kathrynvross@gmail.com. 
of the body/mind and the context (the umwelt) in which organisms dwell. In the sections to follow, I present twelve propositions that I believe explain my understanding of what biocultural semiotics is to date. As always I welcome criticisms, comments, and new ideas.

I believe semiotics is about reality, though few would claim that we know what that is. Peirce was optimistic that science and the scientific method would gradually bring about a consensus on what certain aspects of reality might be. I leave reality to the scientists and philosophers and wish them luck. I, however, deal in dissecting what claims to be reality, but is not. Among these claims are those dealing with racial or ethnic superiority, Western notions of primacy, how we believe our bodies belong to us, how diseases such as Gulf War Syndrome are formulated and become a "reality", why our nature and our culture are inseparable, and so on. I am especially interested in picking apart the artificial lines drawn between the disciplines of biology and the social sciences with rare collaborative effort between the two.

I am a medical anthropologist and not a biologist, though I do my best to understand the biologists, the geneticists, the medical practitioners, and at least some of the kindred disciplines. Because of my training and thirty years of research, my focus here is on the human body. Nevertheless, I believe much of what I argue can be applied to all organisms, at least those that can be said to have culture in any sense by which I mean those that are capable of learning and passing on that learning to the next generation through means that are not genetic. From the time that I was first introduced to semiotics sometime in the 1970s, I have believed that semiotics possesses the capability to unify many academic fields as nothing else does. I end this introduction with statements from some well-known semioticians:

In the expanding intellectual universe of contemporary science, semiotics provides an environment in which specialists from many fields converge toward an interdisciplinary union. (Anderson et al. 2010[1984]: 381)

The phenomena of recognition, memory, categorization, mimicry, learning, and communication are thus among those of interest for biosemiotics research, together with the analysis of the application of the tools and notions of semiotics [...] in the biological realm. However, what makes biosemiotics important and interesting for science in general is its attempt to research the emergence of semiotic phenomena, and together with it, to pave a way of conjoining humanities with natural sciences, culture with nature, through the proper understanding of the relationships between 'external and internal nature' [...]. (Kull 2007: 2) 
Proposition 1: Biology and culture are so bound as to make a discussion of either without inclusion of the other impossible.

We suggest that the insulation between the conceptual sciences and the natural sciences is as counterproductive as that within the various branches of the humanities, social sciences, and natural sciences. (Anderson et al. 2010[1984]: 383)

My first article published in Semiotica (Staiano-Ross 1979) was based on three months of research in a Pentecostal Holiness church located in the American Midwest. I explained how I believed members of the church could cope with suffering and personal failure in their lives outside the church by reference to parallel mythologies of failure, defeat, and success that were prominent within the church. While I still believe in the value of this article, in retrospect I realize I totally missed the biological aspect of performances within the chuch, the manner in which each member's experience became embedded in the body - not just the individual body but in the group body.

And in my initial 18 months of field work in Belize looking at beliefs about illness and its treatment among a variety of ethnic groups, I only once attended a $d u g u$ and then only for a few hours. I was more interested in the pragmatic - and this was a pragmatic society focusing on what worked in treating disorder including disease and how to access the necessary treatment using whatever resources were available. The $d u g u$ was a highly sensational performance, involving music, dance, shamans (buiai), and spirit possession. Only when I returned for three more months of research, did I spend any time in the dabuiaba (temple) during a ceremony and only at the invitation of an elderly bush doctor with whom I had begun what was to become an important collaboration. I recall quite vividly that neither the bush doctor nor his daughter was able to walk to the dabuiaba and I was asked to take on the job of carrying a live rooster through the streets of town and to the temple, dressed in appropriate ceremonial costume which someone had loaned me. A live rooster carried upside down can still raise a ruckus and my thought at the moment was, "If my friends could see me now". Even this experience had a significant biological impact, though I did not consider it at the time.

I only began to wonder about the biological component of such events when later I attended my second $d u g u$ at the invitation of the buiai, the individual who presided over the ceremony and helped bring the spirits of the ancestors (gubida) into the temple. I was one of the first if not the first Anglo ever allowed to film the dugu. However, when one of the two families sponsoring the $d u g u$ became angry with my filming, charging that the spirits were not presenting themselves because of the presence of the camera, I left. I later heard there was talk amongst some about killing me. 
But what was happening there? The almost continuous music, the drumbeat of three drums, the dark and mystical setting inside a dabuiaba, the intense odour of incense, dancing by and among the participants which proceeded through the day and well into the night, the gauisa, who led the singing and knew all the ancient songs, the buiai and his attendants - how did this alter the chemistry of the body to allow spirits of the ancestors and occasionally an evil spirit to enter into the dabuiaba and into the bodies of even the least willing participant. Totally rational people who were or became friends of mine, including the buiai, even those who did not want to be possessed, who did not desire to hear from ancestors, those who had returned from comfortable lives in the U. S. and other nations only because the family demanded it, were possessed. Was it not just a cultural performance but a biological one as well? What, exactly, allows the body to be so penetrated? Was the body altered historically and biologically after generations of attendance at dugus? Was the ability to take on the spirits something so built into the culture after twenty generations that it was now integrated into the body itself? I believe without this thorough weaving of culture into biology and biology into culture, the $d u g u$ would become a forgotten ceremony. ${ }^{2}$ But instead, even as the bush doctors fade away, the dugu assumes even greater prominence.

I could find other examples, including what occurred to me during my attendance in the Pentecostal church, but is this necessary? Is not our biological constitution constantly influenced, if not directed, by culture - and vice versa? We frequently have hormonal responses to even the simplest stimuli. And how are our bodies guided, prodded, and infiltrated by the cultural umwelt within which we live on an everyday basis?

As mentioned earlier, I am a medical anthropologist and my primary concern is with the human body. The dugu is a healing ceremony and people generally claim afterwards that the dugu "worked", that is, the patient recovered or some anticipated but undesired event, such as the death of a family member, did not occur. The same appears to be true with the fascinating phenomenon known as the placebo effect. Do we have the same mechanisms occurring in both? Recent mental health literature suggests that many popular anti-depressants are no more effective than placebos. Pharmaceutical companies sometimes compare the effectiveness of their medications to other, usually older, drugs, rather than to placebos because the comparison might be startling. It seems to me that together biosemioticians and ethnosemioticians could usefully explore these phenomena.

2 In general, the absence of bush doctors today is due to the aging of the population and the inability of most to find interested students. 
Proposition 2: Umwelt is a component of every organism's existence and must be considered central to a biocultural semiotics.

Writing almost a century ago, Jakob von Uexküll argued that all biological organisms possess a self-world, or umwelt, also described as subjective universe, significant surround, or phenomenal world.

[...] for all that a subject perceives becomes his perceptual world and all that he does, his effector world. Perceptual and effector worlds together form a closed unit, the Umwelt. (Uexküll, J. 2010 [1934]: 91)

And a bit later in the same article:

When we die, our sun, sky, and earth will vanish; but they will continue to exist in a similar form in the Umwelts of succeeding generations. There are not only the two varieties of space and time, in which objects are distributed. There is also the variety of Umwelts, in which objects assume a multiplicity of ever new and different forms. At this third level, the countless Umwelts represent the keyboard upon which nature plays its symphony of meaning, which is not constrained by space and time. (Uexküll, J. 2010[1940]: 114)

Again, in the same work, A Theory of Meaning, Jakob von Uexküll stated that the discipline of physics fails to explain the world in the same manner in which biology can:

Biology, on the other hand, shows the untrained observer that he sees far too little, that the real world consists of a multitude of subjective worlds that may be similar to his own, but whose variations he could spend a lifetime studying and never reach an end. (Jakob von Uexküll 1928, quoted in Favareau 2010: 81)

Hoffmeyer (2008: 171) describes the umwelt as "[...] the ecological niche as the animal itself apprehends it”. Umwelt, for Krampen (2010[1981]: 264) is: “[...] the subjective world of what is meaningful impingement for the living being in terms of its own information processing equipment, sign systems, and codes".

Kull (2010b: 348), writing on umwelt and Uexküll's somewhat lesser known term, Innenwelt, tells us that:

The Umwelt is the modelled part of the functional world, whereas the modelling process belongs to the part that Uexküll has called Innenwelt. The Innenwelt is like a cognitive map that relates the self to the world of objects, the Umwelt being the objective world. 
Kull (2010a: 43) further explains:

Description of somebody's Umwelt will mean the demonstration of how the organism (via its Innenwelt) maps the world, and what, for that organism, the meanings of the objects are within it.

The term Innenwelt seems to continue to be utilized much less frequently these days and the term 'endosemiotics', first coined by Sebeok (1976: 73) and referring at that time to the study of cybernetic systems within the body, seems to have replaced it, though the two do not appear to refer to the same phenomena. Thure von Uexküll, Geigges and Herrmann (1993:5) expanded upon this notion of endosemiotics to incorporate all processes of sign transmission inside the organism and not just to regulatory signalling, such as occurs within the immune system or the cardiovascular system.

A few authors have argued that endosemiosis refers to signalling mechanisms within the body, including those meant to regulate the organism and direct it towards survival. If this is the case, then exosemiosis is the obvious term to refer to all signs generated outside the body. To lump all the work of the many semioticians dealing with signs and symbols in various contexts and from a countless variety of perspectives outside the body is to risk offending them. I do not wish to engage in a word game with obviously well-established and thoughtful semioticians, but I do want to further complicate the discussion, pointing out that I think we need to reconsider our terminology. The use of these terms further separates the inside and the outside of the body, which I am suggesting we should discontinue if we are to make progress in semiotics.

As a medical anthropologist with strong interest in religious influences on thought and action, I have had the opportunity to witness many instances of trance possession and speaking in tongues. Some of them are obviously fake, an effort to stimulate and bring to action others in attendance, but often these moments are not. My opportunities to witness trance possession occurred during several dugus I attended in Belize. The intention of the dugu is to call back the ancestors so that they may communicate with their family members, to express their disfavour of certain current practices, such as a failure to maintain certain cultural traditions, to tell family members that they are happy (or otherwise) where they are, and to make requests. Who will be possessed is unpredictable and sometimes those who do not wish to be possessed are the very family members selected by the ancestors. But what I want to bring attention to here is the context within which this happens. What is the effect of the rhythmic throbbing of the heart drum in a dugu, the almost continuous dancing, the sound of fifty roosters tied unhappily beneath 
the benches on which participants sit, to be sacrificed in the morning and fed to the ancestors? Are the sensations thus generated to be attributed merely to the sense of hearing? The drums throb to the rhythm of the heartbeat and the beat enters into the floor and pounds upward into the body. The buiai who, along with a variety of assistants, manages the performance of the $d u g u$, is himself possessed by spirits of departed buiais at various moments throughout the five days of the event. I once asked a buiai what he would do if an evil spirit entered the temple (dabujaba). He replied simply that he did not know as it had never happened. Many steps are taken to discourage evil spirits from entering. The next morning I returned and the buiai came to me and said an evil spirit had got into the temple and possessed a woman the previous night. He was asleep in a separate room in the temple and was immediately alerted to the presence of the spirit. He said he had no idea what to do but went to the woman and knelt on the ground with her. At that moment, his spirit helpers came to him and told him, step by step, what to do and the woman recovered. He was quite surprised by this appearance of his spirit helpers and has little to no memory of the actual event. In the majority of countries which place exceptional reliance on a biomedical model and emphasize rational thinking, such behaviour likely would be considered psychotic, to be treated by medical professionals. However, my friend the buiai appears quite normal without any evidence in my opinion of any psychiatric disturbance. Yet here we are with inputs which cannot be fully categorized by the senses affected, in which the body boundary is violated and we are dealing with signs which easily cross the border, altering body and self in the process, and spurring participants to action.

What about all the other phenomena of this sort in which the body boundary is broken and a sign transmitted from outside becomes internalized. How about the sensation of cold which chills the bones? That is not due to the sensation of touch. And the pounding of the drums which travels upward into the body - that is not touch, nor can it be attributed to the kinesic sense. And the effect of music on both cells and people, the former having no sense of hearing and the latter believing that music is performance which is much more than sound alone. And pollutants of which we are often unaware which enter the body in seemingly mysterious ways and cause often mysterious new disorders of the body? And what of the powerful effect of the placebo which to date no one seems to fully understand. Interestingly, the effect of the placebo seems to vary across national groupings.

The sign is transmitted within the body and, very often, is directly transmitted outward as a new kind of sign, an emotional response, a physical complaint, a protest, life and death. This is what is meant by semiosis, the unlimited process in which a sign never remains the same for more than an instant and why I firmly 
believe we should not divide the world into nature and culture, biology and beliefs, body and umwelt. I do not believe that a sign ever dies, but simply acquires new forms, new interpretants, as it moves across all boundaries.

Just as I believe and have previously argued (Staiano-Ross 1992) that inside and outside of the body are the same, so I believe we should perhaps rethink our division of the field of semiotics into things inside the body and things external to it. After all, what we perceive as reality, our own significant world, is nothing more than what lies beyond the body boundaries translated into thought and models of thought, which are certainly internal to the organism. In fact, the "other" is nothing more than our assessment of what lies out there, whether "other" represents survival or danger. And all symbolic systems must become internalized to function appropriately. Symbolic systems or models which are unrecognized by us are never part of our umwelt and thus never part of what lies within the body.

Proposition 3: The sign is central to biocultural semiotics, just as it is to all forms of semiotics.

We suggest, nodding to Peirce, that the universe originated with the sign. (Anderson et al. 2010[1984]: 401)

I believe the sign, as Peirce defined it, remains the central concept in a biocultural semiotics. Signs are the most powerful force on this planet Gaia and all the world is accessed through signs. We operate within this world through our mastery of signs, always engaged in a semiosic process in which no sign remains the same but is constantly subject to objectification and interpretation. Of course, over time we may lose signs altogether.

During a dugu in which I was a participant observer, I was imaging the bodily sign at one moment, when I suddenly saw how the external sign - a mere sound, a moment in music, a vision, even a natural event, as in a sudden rain storm, passed through the skin and into the body where it was transformed perhaps a hundred times, a thousand times, a million times, and was then expressed as another sort of sign, possibly an action or a word or the release of some chemical. The seeming barrier between the organism and the external sign vanished. Just as this sign had been transformed many times over in the past until it passed into the organism, it was transformed internally, and once expressed was transformed again. Every sign is regressive, that is, has a history, and progressive, that is, has a future, though as I noted above, a sign may be lost to history or an earlier time without history. Nothing we see or hear or feel or imagine ever remains the same a second later. Nothing is static and there is only movement or semiosis/semiogenesis. Beliefs, 
emotions, physical states, and the context within which they occur are expressed as signs, modelled as sign systems. This is as true for any encultured organism as it is for humans. Every external sign has the potential for creating an internal sign.

I need not say more at this point on the importance of the sign, but would like to end with this quote from Thure von Uexküll (2001: 281):

[...] signs are [...] the only true reality; and the rules and laws under which the signs and sign processes communicate themselves to our mind [...] are the only true laws of nature.

Proposition 4: Every sign is an act of communication.

Every sign expressed on or within the body is a form of communication. The body consists not of static parts but constantly communicating cells and organs engaged in an exchange of messages within the organism and with the social and physical environment in which it exists. (Staiano-Ross 2010: 264)

All signs, whether internal to some organism or external, bear information of value, though not universally of value. That is, many if not most signs have value only to a singular group of organisms. The interpretation of the sign leads to some action or response, which then serves as another sign. Within the organism, such signs and responses are assumed to be intended to maintain the equilibrium of the various systems which are, in turn, intended to lead to survival of the organism. Still, while we often speak of the coherence of an immune system which is prepared to respond to virtually any foreign attack upon the organism, autoimmune disorders are generally ignored though they affect estimated 7-8\% of the population and are often passed down to the next generation. Autoimmune disorders are conditions in which the system of communication goes haywire and the body's immune system attacks some organ or multiple organs in the mistaken "belief" that the organ presents a danger to the stability of the organism as a whole. I believe these should be of great interest to biosemioticians and anthropologists exploring the biological changes which may affect a population.

Internal signalling within the body communicates to specific systems intended to receive and interpret such signs and such signals may reach a level that signals distress or some more positive reaction. Signs within the social collectivity are largely intended to do the following: (1) maintain the integrity and coherence of the societal system; (2) alert the community as to errors or mistakes in signaling or in interpretative actions; (3) result in actions to return the community to normal functioning, which may or not be successful. Such failures to return the system to normal are the very basis of human evolution. 
Thus, whether we are discussing internal or external systems, sign processes function in a similar manner. Employing the concept of the sign allows us to traverse the supposed boundary between the body and the community to explore further systems of communication between the two.

Proposition 5: Every sign has its interpretant.

Given Peirce's indeterminancy [...] we cannot hope once and for all to pin down a given sign and its meaning within the semiosic flow. Determination of the interpretant is never final insofar as a finite semiotic agent is concerned. (Merrell 1997: $18)^{3}$

No sign is complete without an interpretant. In semiosis, the interpretant is not an end point but a starting point. That is, the interpretant in and of itself cannot be the equivalent of the meaning of a sign. Though we may interrupt the semiosic process at any point to ascribe meaning to whatever interpretant exists in that point in time, correctly or incorrectly, consciously or unconsciously, that meaning will only exist for a moment. After all, according to Peirce, all thought is in signs and thought does not have an end. One thought generates the next or rather one interpretant generates another; this process does not end with sleep, as dreams are also a form of thought. But neither thought nor the transmission of signs within the body of any organism or between organisms is necessarily linear, but potentially generative of many new signs sometimes independent of one another and independent of the starting point, should there be one. Kant seems to have recognized the semiosic process with respects to certain kinds of signs as we see in the following excerpt:

Prognostic signs are the most interesting of all, because the present is but a moment in the series of changes, and human desire leads us to ponder the present only for the sake of future consequences [...]. (Kant 1798, quoted in Clarke 1990: $55-57)$

Interpretation occurs within or without the body as a part of the semiosic activity, though we may attempt to halt the semiosic process to determine the object's, representamen's, or interpretant's "meaning". For example, we may look at our national flag and assume the object for which it "stands" has meaning, but that meaning will vary across individuals or groups. Because the supposed reality

3 In Merrell's excellent book, the Master presides over a debate between Alpha and Omego. I assume that Merrell has taken on the role of Master and therefore attribute this quote to him. 
of both the representamen and the object is a fictive event, meaning is as well, though true enough to the interpreter who may convince others that the interpretation offered is based on fact. And perhaps it is, but as observers can we ever separate ourselves from that which is observed? We are so immersed in our own cultures that we may never observe or interpret objectively. This caution applies to the biological endeavour as well as the cultural one. That is, as I have argued already, even biological responses are culturally embedded and neither biologists nor anthropologists are free from their methods of perception or their biases.

But here, I wish to turn more deliberately to a discussion of the human body and my thoughts about the activity of interpretation. Think of the body as a complex communicative system in which life and health are sustained by the effective transmission of messages from without the body through our senses (of which there are many more than the five or six senses we normally think of/in) to various parts of the nervous system where perceptions are created and then to the appropriate controlling systems (e.g. endocrine, immunological) ${ }^{4}$ where a series of responses are created which, in general, but not always, keep the body in a healthy state. From here, signs are forecast into a specific scientific and social world, for example, as a rash which has both a medical and a cultural meaning. I could mention the various systems of the body as conceived by biomedicine, but also would point out that systems of control within the organism have been differently conceived by different cultures and vary dramatically over time as well. There is, however, near universal agreement that the body is composed of systems, though not necessarily the biomedically identified systems, each of which has a role in maintaining the body as a healthy organism or protecting the body as a whole from evil spirits and dangerous organisms.

What happens inside/outside the body is always the subject of interpretation at some level.

5.1. By the body itself which must take in the signal or sign that crosses from the outside world into the body, or from within, evaluate whether the sign is of significance (has meaning to the organism or some component of the organism), determine when and where the information should go and the form in which it should be transmitted (few messages being fully formed in the original sign), and how this information is to be utilized.

5.2. By the social and selfish individual, who is always interested in the outcome for him/herself first and foremost and who must consider whether the ensuing

4 We may assume that the notion of systems within the body or the society may be mistaken. 
awareness of the internal event is of importance for the physical or social survival of the self.

5.3. By significant others who may genuinely be concerned about the "victim" of the internal error, if such occurs, but also have their own interests in mind, such as how does this reflect on or affect me.

5.4. By professional interpreters who receive prestige or recompense for their interpretation of the state of the victim. Note that professional interpreters are guided by whatever model dominates the social and medical system at the time. As someone who has worked for several years in hospitals and reviewed many patient's charts in both the US and Belize, and discussed cases with bush doctors, I found the professional's judgment is based on a number of factors, including prior knowledge, the particular model of the body within the cultural setting, the appropriateness of the interpretation judged by the relevant community of professionals, the community of potential sufferers, and the governing system which generally has a vested interest in maintaining compliance with the dominant model. Though Garifuna bush doctors, with whom I spent many hours, are sometimes trained by another bush doctor and sometimes receive their knowledge in an on-going relationship with a departed bush doctor or buiai and sometimes incorporate aspects of "hospital" medicine into their practice, and thus develop independent interpretations of a patient's situation, they all stick to certain principles which are generally agreed upon by the immediate social group. I mention here a characteristic of "bush" medicine and spiritual healing practices which is common throughout the world: interpretations go beyond the body and seek out causation and meaning in the social and personal environment of the patient, into the umwelt of the individual and his/her relationships. This is an element which is often missing in biomedicine where "disease" seems to be restricted to the victim and the wider social and environmental world are of little interest.

5.5. By the social collectivity, which is the broader group, usually organized according to some principle, such as closely held interests or important extended family relations, or restrictions on movement (as in ghettoized or prison populations). The social collectivity, of course, has its own self-interests. Diseases, for example, which are believed to be the result of deviant behaviour label and often isolate the victim.

5.6. By the professionally dominant group which generally insists on certain signs and symptoms being defined in accordance with accepted protocol. The members 
of this group are generally well-organized and have effective lobbying skills at upper political levels where economic decisions determining recompense are effected.

5.7. By the politically dominant group whose interests most commonly coalesce with those who dominate economically. This coalition virtually always has a vested self-interest in how illness is described, what its origins may be, how it is to be treated, and whether it is to be treated. The resulting inequities in care lead to differential morbidity and mortality and the practices which bring this about are sometimes termed "structural violence". For example, while I was in Belize, measles broke out in the Toledo District. The Mayan villages were especially impacted. A medical missionary group volunteered to go into the highlands and vaccinate the children against measles. The government of Belize refused, stating they were capable of taking care of their citizens. No vaccinations took place and I saw the bodies of otherwise healthy appearing Mayan children brought to the Punta Gorda Hospital where they died. The growing Mayan population in the southern district is often regarded as intrusive and of the lowest ranking.

Proposition 6: Perception is influenced by our physical and cultural umwelt.

We have therefore wanted to say that all our intuition is nothing but the representation of appearance; that the things that we intuit are not in themselves what we intuit them to be, nor are their relations so constituted in themselves as they appear to us; and that if we remove our own subject or even only the subjective constitution of the senses in general, then all constitution, all relations of objects in space and time, indeed space and time themselves would disappear, and as appearances they cannot exist in themselves, but only in us. (Immanuel Kant, in Rohlf 2020$)^{5}$

But since we grasp the world only through the structures of our minds, we can't [...] truly know the world in itself. (Pinker 2007: 158)

Perception occurs through our vision, auditory, olfactory, gustation, and touch senses as well as our sense of body position (kinesthetic or vestibular sense) and movement in space (proprioceptive sense), and perhaps many other senses of which we are as yet unaware. Other organisms certainly have perceptive abilities we do not possess, though we may not know how to look for them. In general, we tend to regard information coming from the objects we examine or experience as

5 See Rohlf, Michael 2020. Immanuel Kant. The Stanford Encyclopedia of Philosophy (Spring Edition; Zalta, Edward, ed.) at https://plato.stanford.edu/archives/spr2020/entries/kant/. 
real, that is, as accurate perceptions of reality. However, as we understand more about each of our perceptual skills, we discover that all such sensations are routed through complex processes before they reach the brain where they are again interpreted, that is categorized, and made available to us and the rest of the body.

I once visited Madame Tussauds wax museum in London. As I entered, I approached an attendant and asked directions as the patrons in line behind me quietly laughed at my error. I thought I was speaking to a human, but it was a wax mannequin. What we perceive as reality is only what our brain informs us is real. We see what we expect to see and once the image passes into memory, we are left only with a sign cloaked in many signs. Our brain is very creative and adaptable.

Let's go back to vision as perhaps our most important sense. At the outset, light bounces off "something out there" and into the eye, entering the cornea first where it changes direction slightly. It then passes through the aqueous humour, then the pupil, then the lens where it changes direction again, then through the vitreous humour.All this happens very quickly - certainly we are unaware of this process - then it reaches the retina, which generates a nerve impulse which travels down the optic nerve to a processing site within the brain. The brain then categorizes the raw data it has received and says "that is a rock", but it requires some experience before the brain can tell us "that is a rock". And when does a rock become a boulder or a pebble? This experience is collected and sorted out of previous experiences, which are very often a part of or directed by the cultural umwelt. By cultural umwelt, I refer to that portion of our umwelt which is primarily cultural and social in origin, and often unique to a social collectivity of some sort, perhaps an ethnic group, a tribal group, defined broadly, a union, a professional group, or a political party. These constitute the set of beliefs about what we see and hear and taste and touch out there. If someone says there is an ultraviolet light or a quark, our reply is "there is nothing there, you are imagining it". This is our response both because we do not have the perceptual capabilities to see that portion of the electromagnetic wavelength and in part because we may have been taught that no such thing exists. Scientists rejected the notion of viruses for many millennia simply because they could not see them. Even the germ was first described only in 1861 . Prior to such discoveries many notions of causation of illness prevailed. Ancient Chinese physicians - and some traditional Chinese physicians today - never named diseases but referred to and corrected various imbalances in the body.

Further interfering with our sense of reality is the fact that the retina only receives or recognizes portions of all the incoming data. It breaks up the incoming information into chunks and sends them off to different locations in the brain to be interpreted and then put back together. What is added or deleted in the process is not fully understood. 
There is no such thing as a pure perception of an object within a sensory channel, for instance, vision. (Damasio 1999: 147)

Each living entity superimposes a taxonomy upon its universe (the system of signs the von Uexkülls call Umwelt) to filter out otherwise unmanageable environmental noise. (Sebeok 2001: 89)

We may suppose that the notion of a taxonomy mentioned by Thomas Sebeok means that certain stimuli in the environment are given priority over others and that some information is eliminated in the need to categorize. A portion of this taxonomy which is laid upon on brain's input is a learned phenomenon and any creature which can be said to be encultured has acquired some portions of this taxonomy. Our argument here is that perceptive ability. especially in humans, is something we acquire over time. We are taught to see. To most, this goes against the grain. We believe we see what is out there. What each of us sees is quite real to us, independently of confirmation by others. Certain philosophers - the realists - once believed that reality was something that we were constantly witness to and not simply an idea in our minds. Peirce and many others past and present, however, have argued that we are so encapsulated in language and culture, that little we witness is actually real. "In effect, the brain structure becomes the information that it receives, and so how it perceives that information determines its future state" (Ratey 2001: 54).

Further, the brain is so dynamic that the portions of the brain dedicated to vision can quickly reorganize their structure in as little as thirty minutes under challenge. The brain is never the same creature over even short periods of time. Experience coming from our physical, social, and cultural umwelt and our Innenwelt alters the brain. "If our view of memory is correct, in higher organisms every act of perception is to some degree an act of creation, and every act of memory is to some degree an act of imagination" (Edelman, Tononi 2000: 101).

Proposition 7: Self is critical to our vision of our place in this umwelt.

The self cannot be itself, but only what it was not during the moment past, and what it not yet is - what it will have been - in the future moment. So how is it possible, if at all, to identify the self's 'internal' other? (Merrell 1997: 60)

Self is thus a process - not an entity, but a continuing and possibly infinite set of interpretants. But if this is the case, how can there be a self? We all believe we know what self is - I am me myself - and yet... When does self arise? Where is self created? How does selfhood vary across organisms? What of certain small marine 
organisms which seem to avoid eating their immediate family, but consume others of their same species? Do they identify self in other closely related selves? And coral, which is a living but immobile animal growing in colonies, often incorporating other organisms during its lifetime. Can we imagine selfhood for such a creature? Perhaps. Some cultural groups, past and present, believe the family unit is the self and there is no such thing as self apart from membership in the family. A friend from Pakistan tells me this sense of self is being altered for women by modern soap operas, a fact of which the men are largely unaware, but one which awards the women greater agency.

I believe that self and self-consciousness originate very early in our biological history, with the first organisms with a somewhat bounded more or less impermeable body, that possessed an immune system, an urge towards survival, and some form of neural system which permitted the collection and transmission of information. Thomas Sebeok, with reference to the work of Prodi, argues that immunocompetence was the starting point in the development of a self:

In short, self-recognition is an intrinsic property of the immune system. This system compels a continuous discrimination of immune cell from foreign protein, self from nonself, except when pathology supersedes normal physiology [...]. (Sebeok 2001: 230)

For Peirce, an awareness of self seems to exist only in much more advanced organisms and is not present in infants. However, once the young child develops selfconsciousness, he states, he/she sees him/herself as the centre of the universe, its only relevant self.

A very young child may always be observed to watch its own body with great attention. There is every reason why this should be so, for from the child's point of view this body is the most important thing in the universe. Only what it touches has any actual and present feeling; only what it faces has any actual color; only what is on its tongue has any actual taste. (Peirce 1958[1868]: 103-114; also CP $5.229)$

This is important to our discussion here, for Peirce maintained that everything we see and experience is perceived from the perspective of self and that self is composed of signs which are always subjective. This is Jakob von Uexküll's umwelt from which we cannot escape even in our imagination, this semiotic world.

Further, this semiotic self or web of semiosis that we call ourselves can never become the other, nor fully understand the other. Here is Sebeok on our search for the other: 
[...] but our respectively impenetrable semiosic orbits are perpetually kept apart by a frigid intergalactic void: the self's perception of any other is composite, partial, and forever incomplete. (Sebeok 2001: 126)

What have other semioticians said about selfhood? Jesper Hoffmeyer suggests no one knows which came first, the cell and its cytoplasm or the RNA which transmitted information: "But no matter [...]. The way I see it we would have to say that a "self" - and hence life - does not exist until both of these versions are present" (Hoffmeyer 1996[1993]: 44).

Hoffmeyer and Emmeche state:

For a system to be living, it must create itself, i.e., it must contain the distinctions necessary for its own identification as a system. Self-reference is the fundament on which life evolves, the most basal requirement. (Hoffmeyer, Emmeche 2007: 34)

For Winfried Nöth, self-reference is a prerequisite of life:

An essentially semiotic feature of life is self-reference. In order to survive, every organism does not only have to interact with its environment. It must also be able to recognize its own identity as different from its environment and to thus distinguish between the self and the other. (Nöth 2007: 147)

I want to return now to the point Peirce made about the infant and Sebeok about the other: whenever self-awareness begins, our bodies are the interpreters; we see and experience the world only from our own perspective, our constructed umwelt provides us with our only knowledge of self. We are a system of signs, or simply a sign, and only experience alters and adds to those signs. We are determined by signs. We are not in our culture. Our culture is in us and we will never escape this regardless of how broad our umwelt becomes.

The upshot is that there is no pure, absolutely autonomous 'I' or self. No sign - or self - is an island, an entity unto itself and absolutely autonomous. We, all signs, are thoroughly socialized [...]. For, to repeat Peirce's words, 'a person is not absolutely an individual', and at the same time, a person's 'circle of society' is a soft of 'loosely compacted person'. (Merrell 1997: 61)

Proposition 8: Epigenetic phenomena influence how genes are expressed and affect the developmental cycle, the phenotype and behaviour.

The epigenome is unique for each individual as is the genome. What is different is that the epigenome is developed after fertilization and is not determined by either parent's chromosomes, at least in theory. Some studies suggest that some of these 
non-genetic inputs may be passed to the next generation and even to the generation beyond that. The story of human evolution can no longer be totally explained in terms of genetic determinism. Theories of evolution are being rewritten.

[...] the internal description of the biological system is realized according to a triad: genetic-epigenetic-phenotypic. Genetic structures can generate phenotype realizations only via epigenetic determination of this process. The epigenetic level gives relevant values to genetic structures, converting the latter into information which is then unfolded into the phenotypic structures of an organism. (Igamberdiev 1992: 130)

At the beginning of this emerging science was Darwin's theory of the origin of species. Darwin was not the first, however, to put forward an evolutionary theory. Lucretius (99 to $55 \mathrm{BC}$ ), a Roman follower of Epicurus, developed a theory of both social and natural evolution that included the concept of "survival of the fittest". His theories were based in part on the earlier belief that all matter was composed of atoms. Darwin, however, was the first to support his theory with observations based on extensive field work and many subsequent years of exploration and thought. Underlying mechanisms of evolution, however, could still not be explained. Then came the notion of genes followed by knowledge of the actual structure of the DNA chain. Genes were then all that mattered and they alone were believed to determine the phenotype.

Currently we are seeing another revolution: the rapidly emerging field of epigenetics. The field of epigenetics has been around for some time and descriptions of what it entails have varied. Interest in the field, however, has grown exponentially in the past few years. The discipline of behavioural epigenetics is of more recent origin. Carey defined epigenetics simply in 2012 when she explained that epigenetics dealt with:

[...] the set of modifications to our genetic material that change the ways genes are switched on or off, but which don't alter the genes themselves. (Carey 2012: 7)

These modifications occur as the result of the methylation and demethylation of specific segments of the DNA and the acetylation and deacetylation of the histones, globular proteins wrapped in DNA. Some methylation of the DNA is necessary to life and health, while other instances of methylation prove detrimental. The same is true of demethylation processes and histone acetylation/deacetylation. These epigenetic markers or marks may determine whether a specific gene is turned on or off (thus affecting the production of a protein). It appears epigenetic states are in a constant flux and this process, according to Moore (2015: 63): 
[...] might efficiently bring about rapid biological change in response to stimulation. In fact, it has become clear that input to a neuron - regardless of whether that input comes from other neurons, or directly from the environment - can alter the epigenetic state of that neuron's DNA, thereby ultimately altering how the neuron functions.

Methyl markers are mostly removed during a very early phase of zygote development. The fetus then, during the process of development, accumulates methyl markers. When an infant is born, it has its own non-genetic methyl markers, but was long ago stripped of the epigenetic markers inherited from its parents' DNA. However, it appears from fairly recent studies (largely of mice, but some studies involving humans from an historical perspective) that methylation and acetylation marks may be passed on to the next generation and even generations beyond, though the mechanisms for this are not fully understood nor fully accepted.

The short story here is that methylation (and its reverse process) and histone acetylation (and deacetylation) can assist in or delay adaptation to changing environments. This is true for higher mammals at the very least. Epigenetic states are dynamic, meaning that with certain changes in the environment (in the broadest sense, including the environment experienced by the fetus and the cultural setting) or with internal inputs, methyl additions to DNA may be erased or modified. The same is true of histone acetylation. Thus, the negative effects of methylation, for example, may be reversed in time. These are processes which begin both within and outside the body and that have only been explored in the past few decades but have caused us to modify our understanding of Darwinism and neo-Darwinism and, ultimately, our understanding of evolution.

There is a recently founded field of behavioural epigenetics that seeks to understand the ways in which individual behaviour changes as a result of environmental (again, in the broadest sense) insult. We now know that methylation/demethylation and acetylation/deacetylation influence the action of neuronal DNA as well as DNA in other cells. Input that generates such changes may be physical (as in a lack of food or the practice of smoking) or psychological (as in parental abuse or absence). When neuronal DNA is altered, it can affect important functions such as memory and learning. If we carry this fact to its furthest limits, it is possible that the beliefs and behaviours of social/cultural populations may be altered in some respect or respects by epigenetic processes that begin outside the body, but affect neuronal development. I suggest, for example, that generations of the experience of discrimination may influence gene expression over time. 
Proposition 9: Body boundaries and the self contained within are cultural and political creations.

\begin{abstract}
Generally, the skin might be considered a user interface that couples us to the outer world. On the one hand, the skin thus serves as a kind of topological boundary; while, on the other hand, its semiotic capacity opens up the world to us - so that the question of where our self begins and ends is not at all an easy question to answer scientifically. (Hoffmeyer 2008: 25)
\end{abstract}

I have witnessed many occurrences of trance possession in which the body/self merges with a self from another world, perhaps the spirit of God, or a world in which ancestors live, or a darker place inhabited by spirits intent on evil, or a spirit intent on conveying a message to others. Sometimes they arrive to tell you they are happy and comfortable in this afterlife and sometimes they come to announce displeasure and to make certain demands before protection of the family is restored. There is no question the majority of participants - on the whole very reasonable, pragmatic, and often quite educated people - believe this unification occurs and that they themselves have witnessed or experienced it.

This raised for me the questions of what is the body and where are its boundaries? Are these exclusively scientific issues? The expanded concept of body boundaries that exists in some societies, that extends body outward into space and back in time, or sees the social unit as a collective organism in which there is no individual self acting against a common purpose, or considers personhood present in all parts of the body, whether separated or not and that ritualizes even the discard of certain body products, does not seem to be prominent in Western nations. These beliefs, often strongly held in non-Western nations or among tribal or ethnic groupings, suggest body boundaries are fluid things. Is our Western attitude to body and its boundaries a result of scientific exploration and reason or are historical factors at play? Among the early Greeks there existed a strong sense of individuality, of the possession of characteristics that distinguished one individual from another, of the notion of personal agency. The European and Euro-Asian societies that followed were closely aligned in this respect to Greek thinking. Categorization was imperative to understanding the world and the body.

Ancient Far Eastern thought, however, had little need for or interest in categories. Self was identified with the roles one assumed and self was altered as roles changed. Even today in highly Westernized Asian countries, the family is central to life and the individual's first priority is to family. Public humiliation or embarrassment of the individual reflects on the family. Seppuku was once employed by Japanese to avoid shame that might reflect on the family. Kamikaze pilots of 
World War II and ISIS fighters of today are willing to give up the body and any self for honour to family and nation. My point here is that concepts of the body and its inviolability, its boundaries, and its uses vary from one social collectivity to the next.

But how is this substantially different from out-of-body experiences which occur under a variety of circumstances in Western countries, or the prayers transmitted over great distances for those who are ill, or the belief in soul migration which is common throughout the world?

But perhaps the body boundary is even more vague in the case of pregnancy. The fetus, a self within a self, something I have created, which I believe is mine and for whom I make decisions. Women who have been pregnant often experience a strong sense of responsibility for the life and happiness of this fetus. The majority, however, believe it is their decision whether the fetus should continue life within their bodies. The ability to make those decisions is gradually being threatened, at least in the U.S. If women are to continue to bear responsibility for the separate and growing organism, then many have come to believe they must be held to account should something go wrong. Women who continue to drink or take drugs during pregnancy may now be imprisoned to protect the unborn. Most commonly, these charges are brought against the poor and minorities.

In 2003, South Carolina convicted a Black woman who had suffered a stillbirth for committing homicide by child abuse. Other, similar cases ensued. More than thirty states may charge a woman with child abuse if she uses illicit drugs. In Indiana, an immigrant woman who attempted suicide while pregnant was charged with first-degree murder. A pregnant woman who crossed a double yellow line and hit another car, killing both people inside, was found not guilty of second-degree manslaughter in the death of the couple, but guilty of manslaughter because she recklessly caused the death of her unborn infant by failing to fasten her seatbelt. She was sentenced to up to nine years in prison. (The Editorial Board of the New York Times Dec. 2018 ${ }^{6}$ )

Ingenious attempts are made to declare the fetus a person. This was initially done in order to declare a double murder in the case of a homicide of a pregnant woman during an act of domestic violence. However, the law is being widened to serve other purposes. In a tax bill passed in 2017 by the U.S. Congress, establishing eligibility for investment in a young child's education, the government extended "personhood" to include a child in utero at any stage of development. Should this

6 The Editorial Board 2018. A woman's rights: Part 1: When prosecutors jail a mother for a miscarriage. New York Times, Dec. 28 can be accessed at https://www.nytimes.com/ interactive/2018/12/28/opinion/pregnancy-women-pro-life-abortion.html. 
legal concept spread further in federal law, any state could control any pregnancy from conception.

Proposition 10: The body is a cultural and political body and its ownership is always contested.

Body is ambiguous, the origin of uncertainty, the source of danger. We should not be surprised then that we are not free to own, protect, privatize, seclude, expose, or utilize our bodies freely without interference from the state. (Staiano-Ross 2005: 66)

If body boundaries are uncertain and culturally and legally adjustable, what of the body itself which we tend to regard as a mass of tissues surrounded by several yards of skin? Social and moral discourse would certainly have me in charge of my body. I am my body, after all, this mass of cells enveloped and defined by skin. And if I identify with my body, then certainly I control this flesh and all its parts. It is not some object I have borrowed and now must return. On the contrary, it has been with me since before my birth. There would appear to be some unification of all my essential parts that leaves me in charge. My body must then be mine to do with as I please. But such is not the case.

The body, both the social body - that is the body whose purposes, organization, appearance, uses, and exchange values are agreed upon by a social collectivity - and the individual body as a token representative of that more substantial body, is so potentially powerful that it must be contained/constrained even in everyday actions.

As Foucault (1977) long ago argued the body is made available to institutions of authority to be surveilled, imprisoned, tortured, mutilated, enslaved and executed. Today, these abuses of body still occur in some countries and some occur in all nations. The body may also be quarantined indefinitely for good or suspect purposes. With the advent of transplant technology, the body, alive or dead, may also be utilized for its body parts.

The mere fact that I have not utilized this body to engage in any crime does not mean my body is not subject to detention or surveillance. My right to privacy is illusionary; [...]. though $I$ am innocent, I may be detained for life. Our bodies are "under surveillance" and "under authority" virtually from birth. (Staiano-Ross 2011: 88-89)

Scientific, legal, political, and social discourses provide the metatexts by which narratives about the individual and body collective are interpreted. Institutions 
outside the control of the individual have the authority to decide the manner in which the body will be allowed to express itself, how and where its labour will be distributed, the nature of its relationships with other bodies, and the process by which it is to be declared alive, dead, ill, inadequate, or no longer iconic. Behavioural and biological abnormalities must always be first and foremost cultural/scientific and legal/political constructions because it is in the interests of the dominant institutions to determine what passes as disorder, a threat to the "natural order", and when interventions are in the best interests of the social or political institution.

I believe I have a say over my body and its parts, even though over time a part or two of me has been removed, generally with my permission. I am willing to share the blood I carry and perhaps a liver lobe or a kidney without much objection. If I urinate or throw up on your rug, you are welcome to that product of my body. When I bleed from a cut or blow my nose, I do not want what I have produced back in my body. These products are no longer "me". Yet those items were once part of my body, indistinguishable from self, and now I am willingly giving them up. A profile of my body may be obtained from one or more of these products. If I am arrested or even detained, I may have to surrender some DNA, but it won't be missed, though a part of my self now rests in some file to be used as someone else determines.

Even my body parts, removed without my knowledge of potential value, may be utilized to create new lines of very valuable cells, as was the case with John Moore's spleen ${ }^{7}$ and Henrietta Lack's cervical cancer cells (Skloot 2010). Unclaimed Chinese bodies, it appears, can legally be stripped of skin and soaked in polymer for several weeks, then exhibited in various poses to the public to the financial benefit of the individual who now owns them. Does taking away the skin remove the last semblance of my personhood? The law says that if the body or some part has been altered for some purpose, it no longer belongs to the person from whom it was derived or the family of that individual. This was the reasoning as well in the Moore vs Regents case.

We have come full circle and find that questions about self, personhood, humanness, and iconicity are as challenging and unanswerable as they were for many millennia. We must begin to answer some of the questions raised here before we allow scientific and legal discourse to overwhelm the social/moral. What persons or institutions will decide what the iconic body will be? Will this be left to lawyers and scientists? Who will make future decisions about the genes we

7 See Moore v Regents of the University of California, Supreme Court of California 793 P.2d 479 (Cal. 1990). 
wish to alter or eliminate and the extent to which we will be able to create perfect humans? And what responsibility will society have to those who never had this option and remain less than "perfect"? What role will the law play in supporting or rejecting scientific or social discourse? What are the underlying political and economic institutions that drive these decisions? Which decisions will be left to individuals or medical ethics committees or to scientists or to the legislators and the courts? We are beginning to understand the questions, but have we the ability to begin answering them?

Proposition 11: Disease and all its congeners are cultural constructs. Sickness and its signs arecreated as part of an ongoing personal, social, and political narrative.

We sometimes forget, however, that disease, whether in its abstract configuration or through its realization in the fevered body, is never read except through the often distorted lens of historical prejudices and mistaken biological assumptions. But disease [...] is not simply an object of our study [...]. It is always an event. It is polysemic, multilayered, historically full, and dynamic, not static. It is constructed over time and encumbered with interpretants according to the needs and preconceptions of those who argue they search only for the truth. (Staiano-Ross 2011: 84)

Disease, illness, sickness, ailment, discomfort, la maladie, la enfermedad, malformity, disability - whatever we choose to call it, 'bodily disorder' has existed since the beginning of humanity and certainly well before. The human body is fragile, not yet fully adapted to the various stresses that exist in its habitat. And it is vulnerable from within, quite capable of deterioration on its own, having never been perfected by evolution alone. Who can describe a body that is static, unchanged over even an instant? The body that remains unchallenged, that is not constantly altered, soon dies.

If an organism can be said to be encultured, then sickness will likely consist of both cultural and biological components, though not infrequently no biological and/or cultural component is identified. Most certainly, the response to perceived sickness is primarily cultural, as even biomedical concepts have a strong cultural component.

I wish here not to discuss medical phenomena alone, as they constitute a somewhat separate specialty, a valid discipline in its own, but to define all bodily states, whether representing 'health' (a term which means many different things to diverse populations) or 'bodily disorder', as elaborate narrative events, subject to constant alterations in the story told. Every bodily state is a tale told from multiple perspectives. And every discipline - biomedicine, zoology, critical 
medical anthropology, history, political science, philosophy - has its own telling and restructuring of this narrative.

The majority of incidents of bodily disorder are unpredictable, inexplicable and unwelcome. Societies or social collectives have constantly attempted to make sense out of these events by structuring them, assigning them to categories or offering an assessment that typically incorporates some notion of causation. In the face of an unexpected failure of the body, especially on a greater scale involving more people, the call for social coherence goes out. This singular or repeated instance of disorder must be narrated to fit cultural/political beliefs. That is, some culturally appropriate blame must be assigned, whether that blame accrues to evil spirits, bad germs, humours, environmental pollution, other ethnic groups, distant nations, miasma, poor parenting, a deficient diet, or abusive behaviour. Among the Garinagu of Belize, a cold is not due to a virus but the personal failure to wear a hat when out in bad weather. Until fairly recently, in westernized countries, doctors blamed a stomach ulcer on the inability of an individual to manage stress even though some patients protested, until a bacterium was found in the bellies of most of those suffering from ulcers. Will Covid-19 among poorer populations be blamed on their poverty? On immigrants bearing disease? The failure to socially distance? Crowded housing where privacy and maintaining distance are impossible? On a government which failed to protect the vulnerable? All are simultaneously cultural and political explanations, evolved out of a disease which has no political bias.

Because of the creation of culture and the forces of evolution, humans are extremely adaptable and often find ideas brought in from outside the social group or broader culture useful. However, such notions must be organized within the larger cultural narrative to become acceptable. With biomedicine now firmly implanted within Garifuna communities, where spirits of many sorts once dominated the narrative, "natural" illness has become a broadly accepted causal notion, incorporated into the personal and social "explanatory model" (Kleinman 1988) and most disordered bodies are brought to the local hospital clinic. Certain sicknesses caused by unseen elements in the environment may now be grouped with other "natural" illness. For example, one's own evil intent towards others may return later to sicken the perpetrator; this is considered "natural". The bite of a poisonous snake is considered "natural" unless an enemy magically placed the snake in the individual's path (obeah). Even while most disorders are now assigned to a "natural" category, there is sometimes believed to be another layer of causation which operates on a separate plane pointing to angry ancestors or disturbed neighbours. These are earlier beliefs which have retained a strong presence in the community and they may well be mentioned along with a "natural" illness. Thus, 
two very different etiologies exist side by side because the notion of causation has been restructured to allow both simultaneously. A logic has been built to support this seemingly irrational response. Of course, one does not take the latter type of illness to the hospital for treatment. However, such concepts are critical to narratives everywhere. For example, the attribution of AIDS to a God set on revenge against homosexuals was expressed throughout the U.S. in the years when the first sad and disordered bodies appeared. At the time of this writing in the U.S. Covid-19 is still believed by some to be a Democratic Party hoax or a result of the Chinese creation of a unique virus which would disrupt America. The decision to wear or not wear a mask has become a purely political one.

Every personal narrative must free the individual sufficiently of guilt for the battle ahead. The past is now examined for possible additional explanations and new information is incorporated when consistent with the personal explanation. The changing recognition of symptoms by self and others must be integrated into the narrative, often in a creative way. Ultimately, the personal story must make sense of a lifetime and be compatible with existing notions of causation. The biomedical chart may mention none of these.

But the social collectivity, from the immediate family to the extended family and beyond, must create an interpretive paradigm which often describes the disordered body in terms of relationships among members of the group. The social collectivity is required to make sense of not only this individual illness but other similar instances of the disordered body in the form of a narrative which meshes and supports existing concepts of illness and its causation. This was evident on the occasion I described above (see p. 452) when I was filming a dugu with the permission of the larger faction of an extended family and the other members of the family complained that the ancestral spirits were not arriving in the dabuiaba to possess the participants because of the presence of the camera.

Disease has been manipulated to achieve the broader, if subtextual, goals of the most powerful. It is to the benefit of those in power, the medical/political/ economic elite - often at odds themselves - to define and categorize bodily disorders to their benefit. When syphilis arrived in England, it was termed the French Pox. During times of plague Jews throughout Europe were accused of having poisoned the wells. The U. S. President at the moment of writing this article calls Covid-19 'Kung Flu'. Non-existent diseases are blamed on immigrants, even though such diseases cannot be found. A single incident of bubonic plague in Honolulu in 1899 caused the blockading of a fourteen-square block area where 10,000 Chinese and Japanese lived. Then a supposedly controlled fire of some buildings followed, but the fire quickly spread throughout Honolulu's Chinatown and killed many (Markel 1997). In 1900, the plague reached San Francisco. Upon 
discovery of a single body, all of Chinatown was quarantined. Some scientists believe that certain mental disorders that appear in the DSM were constructed to discriminate against minorities and women or created to assure payment to therapists (Kutchins, Kirk 1997; Harrington 2019). Relatively powerless soldiers returning from the first Gulf War gave their collective disorders a name - Gulf War Syndrome - in order to gain some recognition of and power over their illnesses. The military, on the other hand, rejected the term out-of-hand and even denied that soldiers had similar complaints. It has been suggested this was done to avoid treatment of the disease and expensive disability payments to victims. The Department of Veterans Affairs eventually came to claim ownership over the majority of those bodies, just as those who otherwise define and delimit disease must claim ownership over the bodies thus produced.

Proposition 12: Today we face both uncertainty and opportunity in the natural and cultural sciences.

Consequently, a biological system possesses certain 'freedom of choice' and 'indeterministic' features. Only the behavior of a model can be accurately predicted; the behavior of a biological system can only be drafted with a variable degree of certainty. (Igamberdiev 1992: 130)

Are complex biological neural systems fundamentally unpredictable? (Anthony Aguirre quoted in Brockman 2019: 2)

Lynn Margulis noted in the 1960s that she believed that the dynamism of eukaryotic cells was acquired from a bacterial symbiont. Of the 30,000 genes in the human genome, 250 have come from formerly free-living bacteria (Margulis, Sagan 2002). But Margulis work goes much further, arguing that of greater importance than mutation in evolution is the acquisition of new genomes through what she and Sagan refer to as symbiogenesis, the merger of one organism or gene containing structure with another. This, they propose, is far more responsible for significant change over time than random mutations. We note that Jakob von Uexküll pointed out the occurrence of a similar process much earlier when he described how single equipotential cells were forced by slime mould to incorporate themselves into the slime mould (Uexküll, J. 2010[1940]: 107).

If the eukaryotic cells owe this ubiquitous feature to symbiosis, biologists must begin thinking of the cell as a complex community of microorganisms [emphasis added] not merely as a unit in larger structures. (Margulis, Sagan 1997: 37) 
This brings me to the question of whether the cell has individuality, as Jakob von Uexküll once famously stated (though Uexküll later went on to qualify that statement), or is totally at the whim of the organ or anatomical system within which it lives. Is every process within the body predetermined or do cells and systems sometimes go astray of their own volition? I believe we should further examine whether arbitrariness, that is choice, is everywhere, possibly down to the level of the individual cell. How can we account for the unpredictability of both the biological and the cultural organism? How does this interaction potentially lead to greater stability in both? And bodies and the umwelts within which they live and construct their reality? To what extent have we examined the individual's biological or human umwelt in depth? Every organism, except the smallest without any evidence of a neural system, must in some manner have constructed over time its own peculiar umwelt. And the individual within even a highly structured collectivity must have his/her own self-constructed umwelt/Innenwelt as well.

Many years ago, when I was a freshman in college, the anthropology department where I was enrolled was organized around mathematics. In more than one case we were asked to examine the mathematics of human behaviour. Game theory and systems theory were important components of this work. We learned that the behaviour of human individuals in a specific situation might be predicted by the mathematics of the context. One of my favourite exercises was predicting whether a bank robber might choose to rob a bank. The variables considered by the bank robber were the amount of money in the bank, the likelihood of being caught, and the cost of a long prison sentence. I'm sure there were additional variables which have escaped me over time, but you get the idea. Each of the variables could be altered. By adjusting these variables, we predicted whether the bank robber might reasonably proceed with his plan. What we did not/could not account for was the individual human's umwelt/Innenwelt - his level of desperation, his need to feed his family, the expectations of his friends, the level of shame he would experience if captured. In other words, such behaviour is never predictable unless we have lived within that individual's umwelt/Innenwelt. Some level of autonomy and unpredictability may be the nature of all cells, all organs, all organisms, up to and including humans and the societies within which they live. At what level does human autonomy, or that of any organism, begin - only at the level of the mind? This is what we tend to believe. But is not mind the Innenwelt and does not the Innenwelt, in theory, function largely on the basis of deterministic actions of the biological systems within the body? How can we have an Innenwelt which is biological in construction yet has the ability to take actions that may conflict with its traditions. And what is the role of neuronal pruning which is very much affected by the society within which the organism lives? 
I want to discuss another set of uncertainties that have been introduced into the physical and the social sciences, perhaps another way in which culture and nature are alike. Ilya Prigogine and his colleagues long ago challenged the notion of time as reversible. But, perhaps of greater importance to our discussion here he has challenged the notion of certainty in the sciences and argues against the world as a deterministic place.

Classical science emphasized order and stability: now, in contrast, we see fluctuations, instability, multiple choices, and limited predictability at all levels of observation. (Prigogine, Stengers 1997: 4)

Loss of equilibrium within a social collectivity as well as a biological system may result in a series of actions that return the system to the normal state or it may create dramatic change within the community. This seems to be the current state of the world. However, chaos, as we now know, can well lead to a movement towards order. Societies, like organisms, are complex adaptive systems.

While Prigogine's work (much involving Isabelle Stenger as co-author) initially referred primarily to physics and related hard sciences, it has come to apply to the social sciences as well. We have seen above how genetic determinism has been successfully challenged. And though the human or other umwelt may place the individual or the social collectivity within a "bubble", may restrict interpretations and actions, the umwelt alone does not determine behaviour.

Concepts which are part of or evolved from Prigogine's work include deterministic chaos, dissipative structures, self-organization, and complexity theory. All of these have been employed in the biological and social sciences as well as in several of the hard sciences. A few examples of this work are offered here. They extend from the quantification of dissipative structures in pre-Columbia agriculture, the use of chaos theory and dissipative structures in clinical practice, the application of complexity theory to organizational structure, the examination of random interactions in biology which lead to order in a system in disequilibrium, and to issues of the future of the human species and planetary equilibrium.

Some of the questions I have posed here, as well as the sizeable number and variety of articles utilizing concepts first proposed by Ilya Prigogine should suggest a number of possible methodologies to use in more closely examining the complex weaving together of the biological and the cultural.

And cannot the common language and concepts of semiotics assist us in these endeavours? I truly hope the answer is 'yes'. 


\section{References}

Anderson, Myrdene; Deely, John; Krampen, Martin; Ransdell, Joseph; Sebeok, Thomas A.; Uexküll, Thure von 2010[1984]. A semiotic perspective on the sciences: Steps toward a new paradigm. In: Favareau, Donald (ed.), Essential Readings in Biosemiotics: Anthology and Commentary. (Biosemiotics 3.) New York: Springer, 381-413.

Brockman, John (ed.) 2019. The Last Unknowns. New York: William Morrow.

Carey, Nessa 2012. The Epigenetics Revolution: How Modern Biology is Rewriting Our Understanding of Genetics, Disease, and Inheritance. New York: Columbia University Press.

CP = Peirce, Charles Sanders. The Collected Papers of Charles Sanders Peirce. (Hartshorne, Charles; Weiss, Paul, eds. 1931-1935; Burks, Arthur W., ed. 1958.) Cambridge: Harvard University Press. [In-text references are to CP, followed by volume and paragraph numbers.]

Damasio, Antonio 1999. The Feeling of What Happens: Body and Emotion in the Making of Consciousness. New York: Harcourt, Inc.

Edelman, Gerald; Tononi, Giulio 2000. A Universe of Consciousness: How Matter Becomes Imagination. New York: Basic Books.

Favareau, Donald (ed.) 2010. Essential Readings in Biosemiotics: Anthology and Commentary. (Biosemiotics 3.) New York: Springer.

Foucault, Michel 1977. Discipline and Punish: The Birth of the Prison. (Sheridan, Alan, trans.) New York: Random House.

Harrington, Anne 2019. The Mind Fixers: Psychiatry's Troubled Search for the Biology of Mental Illness. New York: W. W. Norton and Company.

Hoffmeyer, Jesper 1996[1993]. Signs of Meaning in the Universe. (Haveland, Barbara J., trans.) Bloomington: Indiana University Press.

Hoffmeyer, Jesper 2008. Biosemiotics: An Examination into the Signs of Life and the Life of Signs. (Hoffmeyer, Jesper; Favareau, Donald, trans.; Favareau, Donald, ed.) Scranton: University of Scranton Press.

Hoffmeyer, Jesper; Emmeche, Claus 2007. Code duality and the semiotics of nature. In: Barbieri, Marcello (ed.), Biosemiotics: Information, Codes and Signs in Living Systems. New York: Nova Science Publishers, 27-64.

Igamberdiev, Abir U. 1992. Organization of biosystems: A semiotic approach. In: Sebeok, Thomas A.; Umiker-Sebeok, Jean (eds.), Biosemiotics: The Semiotic Web 1991. New York: Mouton de Gruyter, 127-144.

Kant, Immanuel 1990[1798]. Anthropology from a pragmatic point of view. In: Clarke, David S. (ed.) 1990. Sources of Semiotic: Readings with Commentary from Antiquity to the Present. Carbondale: Southern Illinois University Press, 55-57.

Kleinman, Arthur 1988. The Illness Narratives: Suffering, Healing \& The Human Condition. New York: Basic Books.

Krampen, Martin 2010[1981]. Phytosemiotics. In: Favareau, Donald (ed.), Essential Readings in Biosemiotics: Anthology and Commentary. (Biosemiotics 3.) New York: Springer, 262-277.

Kull, Kalevi 2007. A brief history of biosemiotics. In: Barbieri, Marcello (ed.), Biosemiotics: Information, Codes and Signs in Living Systems. New York: Nova Science Publishers, 2-26. 
Kull, Kalevi 2010a. Umwelt and modeling. In: Cobley, Paul (ed.), The Routledge Companion to Semiotics. London: Routledge, 43-56.

Kull, Kalevi 2010b. Umwelt. In: Cobley, Paul (ed.), The Routledge Companion to Semiotics. London: Routledge, 348-349.

Kutchins, Herb; Kirk, Stuart A. 1997. Making Us Crazy: DSM: The Psychiatric Bible and the Creation of Mental Disorders. New York: The Free Press.

Margulis, Lynn; Sagan, Dorion 1997. Slanted Truths: Essays on Gaia, Symbiosis, and Evolution. New York: Springer-Verlag. https://doi.org/10.1007/978-1-4612-2284-2

Margulis, Lynn; Sagan, Dorion 2002. Acquiring Genomes: A Theory of the Origins of Species. New York: Basic Books.

Markel, Howard 1997. Quarantine! East European Jewish Immigrants and the New York City Epidemics of 1892. Baltimore: The Johns Hopkins University Press.

Merrell, Floyd 1997. Peirce, Signs, and Meaning. Toronto: University of Toronto Press. https://doi.org/10.3138/9781442678330

Moore, David S. 2015. The Developing Genome: An Introduction to Behavioral Epigenetics. Oxford: Oxford University Press.

Nöth, Winfried 2007. Semiotics for biologists. In: Barbieri, Marcello (ed.), Biosemiotics: Information, Codes and Signs in Living Systems. New York: Nova Science Publishers, 141-153.

Peirce, Charles S. 1958[1868]. Selected Writings. (Wiener, Phillip P., ed.) New York: Dover Publications, Inc. [Originally published as: Questions concerning certain faculties claimed for man. Journal of Speculative Philosophy 2: 103-114.]

Pinker, Steven 2007. The Stuff of Thought: Language as a Window into Human Nature. London: Penguin Books.

Prigogine, Ilya; Stengers Isabelle 1997. The End of Certainty: Time, Chaos, and the New Laws of Nature. New York: The Free Press.

Ratey, John 2001. A User's Guide to the Brain: Perception, Attention, and the Four Theaters of the Brain. Toronto: Random House.

Rohlf, Michael 2020. Immanuel Kant. The Stanford Encyclopedia of Philosophy (Spring Edition), Zalta, Edward N. (ed.) <https://plato.stanford.edu/archives/spr2020/entries/ kant/>.

Sebeok, Thomas A. 1976. Contributions to the Doctrine of Signs. Bloomington: Indiana University Press.

Sebeok, Thomas A. 2001. Global Semiotics. Bloomington: Indiana University Press.

Skloot, Rebecca 2010. The Immortal Life of Henrietta Lacks. NewYork: Crown Publishers.

Staiano-Ross, Kathryn 1979. A semiotic approach to ritual drama. Semiotica 18(3/4): 225-246. https://doi.org/10.1515/semi.1979.28.3-4.225

Staiano-Ross, Kathryn 1992. Biosemiotics, ethnographically speaking. In: Sebeok, Thomas A.; Umiker-Sebeok, Jean (eds.), Biosemiotics: The Semiotic Web 1991. (Approaches to Semiotics 106.) New York: Mouton de Gruyter, 407-426. https://doi. org/10.1515/9783110871388-022

Staiano-Ross, Kathryn 2005. Losing myself. Semiotica 154(1/4): 57-94. https://doi. org/10.1515/semi.2005.2005.154-1-4.57

Staiano-Ross, Kathryn 2010. Medical semiotics. In: Cobley, Paul (ed.), The Routledge Companion to Semiotics. London: Routledge, 264-265. 
Staiano-Ross, Kathryn 2011. Quarantine. Semiotica 187(1/4): 83-104. https://doi.org/10. 1515/semi.2011.065

Uexküll, Jakob von 2010[1934]. A stroll through the worlds of animals and men. In: Favareau, Donald (ed.) Essential Readings in Biosemiotics: Anthology and Commentary. (Biosemiotics 3.) New York: Springer, 90-91.

Uexküll, Jakob von 2010[1940]. The theory of meaning. In: Favareau, Donald (ed.) Essential Readings in Biosemiotics: Anthology and Commentary. (Biosemiotics 3.) New York: Springer, 91-114.

Uexküll, Thure von; Geigges, Werner; Herrmann, Jörg 1993. Endosemiosis. Semiotica 96(1/2): 5-51. https://doi.org/10.1515/semi.1993.96.1-2.5

Uexküll, Thure von 2001. Varieties of semiosis. In: Sebeok, Thomas A.; Umiker-Sebeok, Jean (eds.), Biosemiotics: The Semiotic Web 1991. New York: Mouton de Gruyter, $455-470$.

\section{Предложения по биокультурной семиотике}

В своих предыдущих работах автор уже использовала термин «биокультурная семиотика», но никогда не определяла эту область. Здесь приводятся двенадцать тезисов, которые описывают и обосновывают биокультурную семиотику. Автор опирается на тридцатилетний опыт полевой работы в Белизе и свои предыдущие исследования по семиотике культуры и биосемиотике в поддержку каждого из предложений. Предложения включают: биология и культура настолько связаны, что обсуждение любого из них без включения другого невозможно; умвельт и знак являются центральными понятиями; каждый знак является актом коммуникации; каждый знак имеет несколько интерпретантов; наш физический и культурный умвельт влияет на восприятие; само (self) имеет критическое значение для определения нашего понимания своего места в умвельте; эпигенетические явления влияют на проявление генов, а те, в свою очередь, влияют на фенотип и на поведение; границы тела образованы культурой и политикой; тело является политическим и его принадлежность всегда оспаривается; болезнь и похожие на нее явления являются культурными конструкциями; знаки болезни создаются как часть личного, социального и политического нарратива; сегодня мы сталкиваемся как с неопределенностью, так и с возможностями в естественных науках и науках о культуре. Автор утверждает, что семиотика обладает необходимым языком и методологией для достижения понимания отношения между биологией и культурой.

\section{Bio-kultuurisemiootika teesid}

Autor on terminit bio-kultuurisemiootika kasutanud oma varasemates töödes, kuid ei ole seda valdkonda varem defineerinud. Käesolevaga esitab ta kaksteist propositsiooni, mis kirjeldavad bio-kultuurisemiootikat ning motiveerivad seda. Ta lähtub kolmkekümne aasta jooksul sooritatud välitöödest Belizes ning oma varasemast teadustööst kultuurija biosemiootika vallas. Teesid on järgmised: bioloogia ja kultuur on omavahel niivõrd seotud, et ühest kõnelemine teist kaasamata on võimatu; nii omailm kui ka märk on 
kesksel kohal; iga märk on kommunikatsiooniakt; igal märgil on mitu tõlgendit; meie füüsiline ja kultuuriline omailm mõjutab taju; Ise on kriitilise tähtsusega, mis puutub meie nägemusse meie kohast selles omailmas; epigeneetilised nähtused mõjutavad seda, kuidas geenid ekspresseeruvad, ning mõjutavad nii fenotüüpi kui ka käitumist; keha piirid on kultuuriliselt ja poliitiliselt loodud; keha on poliitiline keha ja selle kuuluvus on alati vaidlustatud; haigus ning sellega sarnanevad nähtused on kultuurilised konstruktsioonid; haigust ja selle märke luuakse osana jätkuvast isiklikust, ühiskondlikust ning poliitilisest narratiivist; tänapäeval seisame loodus- ja kultuuriteadustes silmitsi nii ebakindluse kui ka võimalustega. Autor väidab, et semiootika valdab keelt ja metoodikaid, et jõuda bioloogilise/kultuurilise vahelise suhte mõistmisele. 